\title{
PENGARUH PEMBERIAN LIMBAH KULIT KECAMBAH KACANG HIJAU TERHADAP ENERGI METABOLIS, LEMAK ABDOMINAL DAN BOBOT BADAN AKHIR ITIK MAGELANG JANTAN
}

\author{
Catur Basuki $^{1}$, I Mangisah ${ }^{2}$ dan B Sukamto ${ }^{3}$ \\ Fakultas Peternakan dan Pertanian, Universitas Diponegoro, \\ Semarang. Jl. Prof.H. Soedarto, S. H. - Tembalang Semarang, Indonesia (50275) \\ Email : basukicatur4@gmail.com
}

\begin{abstract}
ABSTRAK
Penelitian ini bertujuan mengetahui pengaruh pemberian limbah kecambah kacang hijau dalam ransum terhadap energi metabolis, lemak abdominal dan bobot badan akhir pada itik Magelang jantan.Magelang jantan. Materi yang digunakan adalah itik Magelang jantan umur 4 minggu sebanyak 120 ekor dengan ratarata bobot badan 930,66 $\pm 136 \mathrm{~g}$. Rancangan percobaan yang digunakan adalah rancangan acak kelompok (RAK) dengan 4 perlakuan dan 5 kelompok. Masing-masing kelompok terdiri dari 6 ekor itik. Perlakuan yang digunakan meliputi $\mathrm{T} 0=$ Ransum kontrol, $\mathrm{T} 1=$ Ransum dengan 5\% tepung limbah kecambah kacang hijau, T2 = Ransum dengan 10\% tepung limbah kecambah kacang hijau dan T3 = Ransum dengan 15\% tepung limbah kecambah kacang hijau. Parameter yang diamati adalah energi metabolis, lemak abdominal dan bobot badan akhir yang diuji menggunakan uji $\mathrm{F}$ tabel. Weight Hasil penelitian menunjukkan bahwa penggunaan tepung limbah kecambah kacang hijau berpengaruh nyata $(p>0,05)$ terhadap energi metabolis dan tidak berpengaruh nyata $(\mathrm{p}<0,05)$ terhadap konsumsi ransum, lemak abdominal dan bobot badan akhir. Kesimpulan dari penelitian ini adalah penggunaan tepung limbah kecambah kacang hijau dalam ransum sampai $15 \%$ menurunkan energi metabolis tetapi tidak meningkatkan bobot badan akhir itik Magelang jantan, serta belum mampu menurunkan kadar lemak abdominal terhadap itik magelang jantan.

Kata Kunci: itik Magelang, limbah kecambah kacang hijau, energi metabolis, lemak abdominal, bobot badan akhir.
\end{abstract}

\begin{abstract}
This experiment was carried out to examinate effects of diets containing mung bean sprouts waste of used of mungbean waste to metabolizable energi, abdominal fat and final body weight of Magelang duck. The materials used magelang male ducks age of 4 weeks with an average body weight 930,66 $\pm 136 \mathrm{~g}$. The design used randomized block design with 4 treatments and 5 groups. Each groups consisted of 6 ducks. The treatments were used $\mathrm{T} 0=$ (control diet), $\mathrm{T} 1=$ (control diet contain $5 \%$ mung bean sprouts waste), $\mathrm{T} 2$ $=($ control diet contain 10\% mung bean sprouts waste $)$ and $\mathrm{T} 3=($ control diet contain $15 \%$ mung bean sprouts waste ). Parameters observed was of used of mungbean waste to metabolizable energi, abdominal fat and final body weight of Magelang male duck., which will be analyze statistically by F tabels. The result showed that were used mungbean waste significantly $(p>0,05)$ on metabolizable energi and had no significant $(\mathrm{p}<0,05)$ on nutrients consumption, abdominal fat and final body weight. It can concluded that were used mungbean waste on ration up to $15 \%$ decreas metabolizable energi but can not improve final body weight and can not decreas abdominal fat.
\end{abstract}

Keywords: Magelang ducks, mungbean waste, Metabolizable Energi, Abdominal Fat, Final Body Weight. 


\section{PENDAHULUAN}

Usaha peternakan itik secara intensif semakin banyak diusahakan oleh para peternak di berbagai wilayah di Indonesia, keadaan ini dikarenakan usaha tersebut cukup menguntungkan. Diantara berbagai jenis itik yang dibudidayakan, itik magelang adalah salah satu itik yang banyak dijumpai. Itik magelang merupakan rumpun itik lokal yang mempunyai ciri-ciri berwarna hitam atau kecoklatan dengan penanda cicin dilehernya serta berpotensi daging dan telurnya (Supriyadi, 2009).

Potensi pemanfaatan itik magelang jantan sebagai pedaging cukup menjanjikan untuk dikembangkan, karena pertumbuhan itik jantan yang lebih cepat bila dibandingkan dengan unggas lainnya, juga sifat itik yang mudah beradaptasi terhadap lingkungan. Pemeliharaan itik dengan sistem intensif menghasilkan produktivitas cukup tinggi dengan kalkulasi biaya pakan mencapai

60-80\% dari seluruh biaya produksi (Mangisah et al., 2009).

Itik memiliki kemampuan untuk mencerna serat kasar yang lebih baik dibandingkan dengan unggas lain. Kemampuan tersebut dapat mendorong peternak itik untuk memanfaatkan limbah (hasil ikutan) bidang pertanian sebagai bahan pakan alternatif, salah satunya limbah kecambah kacang hijau.

Limbah kecambah kacang hijau sering kali dianggap tidak bermanfaat dan mencemari lingkungan. Namun melihat kandungan gizi yang terdapat pada limbah kecambah kacang hijau yang menggandung serat kasar tinggi, maka limbah tersebut kemungkinan dapat dimanfaatkan sebagai bahan pakan alternatif. Selain itu, bahan pakan dengan kandungan serat kasar tinggi memiliki harga yang lebih murah.

Hasil analisis proksimat di laboratorium Ilmu Nutrisi Pakan, Universitas Diponegoro, Semarang diperoleh bahwa $0,33 \%$ lemak, $36,82 \%$ serat kasar (SK) dan $10,05 \%$ protein kasar (PK) dalam $87,37 \%$ berat kering (BK). Serat kasar merupakan salah satu zat makanan penting dalam ransum unggas, karena memiliki fungsi merangsang gerak peristaltik saluran pencernaan sehingga proses pencernaan zat-zat makanan berjalan dengan baik. Hal tersebut membuat nilai kecernaan akan semakin baik. Nilai kecernaan yang membaik berpengaruh terhadap peningkatan nilai energi metabolis (Abun et al.,2007).
Kandungan energi metabolis dalam ransum sangat penting karena menggambarkan nilai nutrien dari ransum. Unggas mengkonsumsi ransum untuk memenuhi kebutuhan energi. Ransum dengan nilai kecernaan yang tinggi akan membuat zat pakan yang diserap tinggi (Yuniarti et al., 2015), sehingga menghasilkan pertambahan bobot badan yang lebih cepat. Kandungan serat kasar yang tinggi dalam ransum akan mempengaruhi lemak abdominal. Menurut Poendjiadji (2005) serat kasar yang berasal dari pakan setelah dikonsumsi akan mengikat asam empedu sesampainya disaluran pencernaan, sehingga fungsi empedu untuk membantu penyerapan lemak akan terhambat. Asam empedu yang sudah terikat oleh serat kasar dikeluarkan dari tubuh dalam bentuk ekskreta, hal ini menyebabkan penurunan deposisi lemak abdominal. Itik memiliki batas maksimal $8 \%$ SK dalam ransumnya untuk mampu dimanfaatkan secara optimal (SNI, 2006).

Berdasarkan uraian tersebut diperlukan pengkajian mengenai pengaruh pemberian tepung limbah kecambah kacang hijau terhadap energi metabolis, lemak abdominal, dan bobot badan akhir itik magelang jantan. Manfaat dari penelitian ini adalah mengetahui tingkat energi metabolis, lemak abdominal, dan bobot badan akhir itik magelang jantan yang mendapat perlakuan pemberian tepung limbah kecambah kacang hijau hingga taraf $15 \%$.

Hipotesis dalam penelitian ini yaitu pemberian tepung limbah kecambah kacang hijau dapat meningkatkan energi metabolis dan bobot badan akhir pada itik magelang jantan serta menurunkan kandungan lemak abdominalnya.

\section{MATERI DAN METODE}

Materi yang digunakan pada penelitian ini adalah 120 ekor itik Magelang jantan umur 6 minggu dengan bobot badan rata-rata 930,66 136 g. Kandang ukuran $1 \times 1,5 \times 1 \mathrm{~m}$ sebanyak 20 petak, tiap petak berisi 6 ekor itik. Bahan pakan yang digunakan terdiri dari jagung, dedak, bungkil kedelai, tepung ikan, tepung limbah kecambah kacang hijau dan mineral mix.

Ransum perlakuan yang diberikan selama penelitian (6-10minggu) adalah $\mathrm{T} 0=$ Ransum kontrol, $\mathrm{T} 1=$ Ransum kontrol dengan 5\% tepung limbah kecambah kacang hijau, $\mathrm{T} 2=$ Ransum kontrol dengan $10 \%$ tepung limbah kecambah kacang hijau dan $\mathrm{T} 3=$ Ransum kontrol dengan 15\% tepung limbah kecambah kacang hijau. Ransum diberikan secara ad libitum. Parameter yang diamati adalah energi metabolis, lemak abdominal dan bobot badan akhir. 
Rancangan penelitian yang digunakan adalah Rancangan Acak Kelompok (RAK) yang terdiri dari 4 perlakuan dan 5 kelompok bobot badan. Kelompok pertama (K1) ; 701-800, K2 ; 801900 , K3 ; 901-1000, K4 ; 1001-1100 dan K5 ; 1100-1101 g. Data yang diperoleh dianalisis menggunakan analisis sidik ragam.

Tabel 1. Komposisi dan Kandungan Nutrien Ransum Penelitian

\begin{tabular}{lcccc} 
Jagung & 40 & 40 & 41 & 40 \\
Dedak & 27 & 22 & 15 & 12 \\
Bungkil & 22 & 22 & 23 & 22 \\
Tepung & 10 & 10 & 10 & 10 \\
Top & 1 & 1 & 1 & 1 \\
Total & 100 & 100 & 100 & 100 \\
\hline Kandunga & & & & \\
EM & 2714 & 2740 & 2776 & 2793 \\
Protein & 19,2 & 19,3 & 19,8 & 19,52 \\
Serat & 7,54 & $\hat{8}, 30$ & $\hat{8}, 66$ & 9,82 \\
Lemak & 4,98 & 4,36 & 3,52 & 3,16 \\
Ca $(\%)^{* *}$ & 0,89 & 0,90 & 0,92 & 0,94 \\
P $(\%)^{* *}$ & 0,41 & 0,40 & 0,38 & 0,37 \\
\hline Sum : Dihy
\end{tabular}

Sumber : *Dihitung berdasarkan Tabel komposisi bahan makanan hartadi.

**Dihitung berdasarkan Hasil analisis proksimat Laboratorium Ilmu

Nutrisi Pakan, Universitas Diponegoro, Semarang (2016).

\section{HASIL DAN PEMBAHASAN}

Hasil penelitian menunjukkan bahwa pemberian tepung limbah kecambah kacang hijau sampai taraf $15 \%$ berpengaruh nyata $(\mathrm{P}<0,05)$ terhadap energi metabolis itik Magelang jantan dan tidak berpengaruh nyata $(\mathrm{P}>0,05)$ terhadap lemak abdominal dan bobot badan akhir.

Tabel 3. Rata-rata Konsumsi Ransum, Energi Metabolisme Ransum, Lemak Abdominal, Bobot Badan Akhir.

\begin{tabular}{lrrrr} 
Energi & 3077, & 2916,9 & 3048,3 & 2905, \\
Lemak & 0,5 & 0,42 & 0,46 & 0,5 \\
Bobot & 1582 & 1549, & 1565, & 1559, \\
\hline
\end{tabular}

Keterangan : Superskrip yang berbeda pada baris yang sama menunjukkan adanya

perbedaan nyata $(\mathrm{P}<0,05)$.

\section{Energi Metabolis}

Tabel 3 menunjukkan bahwa nilai energi metabolis ransum pada perlakuan T1, T2 dan T3 memperlihatkan perbedaan nyata dengan T0, Ratarata nilai energi metabolis menunjukkan bahwa penggunaan limbah kecambah kacang hijau dalam ransum menurunkan nilai energi metabolis ransum, Hal ini dapat dipengaruhi oleh kecernaan serat kasar pada T1,T2,T3 nyata lebih rendah dari T0. Hasil pengamatan dari pemberian limbah kecambah kacang hijau hingga taraf $15 \%$ terhadap persentase kecernaan serat kasar ransum ( $\mathrm{T} 0=30,13 \%, \mathrm{~T} 1=24,59 \%, \mathrm{~T} 2=24,22 \%, \mathrm{~T} 3=24,28)$. Pangestu., et al (2018) menyatakan bahwa ransum dengan kadar serat kasar yang tinggi menyebabkan kecernaan bahan pakan dan penyerapan zat-zat makanan menurun sehingga menurunkan kandungan energi metabolis, Pada ransum dengan perlakuan T0 memiliki kandungan serat kasar lebih rendah daripada perlakuan lainnya. Hal tersebut menunjukkan ransum dengan nilai serat kasar rendah memiliki konsumsi yang lebih banyak, Meningkatnya konsumsi ternak membuat asupan nutrien yang digunakan untuk energi semakin banyak, Hal tersebut berdampak pada nilai energi metabolis yang meningkat, Hal ini sesuai dengan pendapat Pramudia (2013) yang menyatakan nilai energi metabolis berbanding lurus dengan konsumsi ternak yang dimanfaatkan menjadi energy.

SNI (2006) mensyaratkan untuk serat kasar dalam ransum itik fase grower kurang dari $8 \%$. Tingginya kandungan serat kasar ini akan menyebabkan itik cepat kenyang. Ransum dengan serat kasar tinggi agak lama untuk dicerna sehingga kecepatan konsumsi juga berkurang(Tanwairih et al.,2006). Imawan et al(2016) meyatakan semakin tinggi serat kasar dalam ransum menunjukkan semakin rendah daya cerna bahan pakan tersebut. Faktor yang mempengaruhi energi metabolis adalah gross energi pakan dan banyaknya energi yang digunakan ternak (Saputra, 2001), Standar kebutuhan nutrisi untuk energi metabolis tergantung pada mekanisme adaptasi suhu lingkungan yang bisa kita lihat dari mengkonsumsi ransum (Anggarayono et al., 2008).

\section{Lemak abdominal}

Pengaruh penggunaan limbah kecambah kacang hijau terhadap lemak abdominal disajikan dalam Tabel 2. Hasil analisis ragam menunjukkan penggunaan tepung limbah kecambah kacang hijau tidak berpengaruh nyata $(\mathrm{P}>0,05)$ terhadap lemak abdominal itik magelang jantan. 
Hal ini dapat dipengaruhi oleh pertambahan bobot badan yang tidak terpengaruh oleh perlakuan. Dewanti et al, (2013) menyatakan berat lemak abdominal cenderung meningkat dengan bertambahnya berat badan, Serat kasar yang terkandung dalam ransum membuat nutrisi dalam pakan tidak terserap sempurna sehingga berdampak pada penimbunan jaringan lemak. Perlakuan pemberian limbah kecambah kacang hijau juga tidak mempengaruhi kecernaan lemak sehingga tidak berpengaruh terhadap sintesis lemak. Menurut Maryuni dan Wibowo (2005) penimbunan lemak dipengaruhi oleh komposisi ransum antara lain tingkat enegi dalam ransum, perbandingan energi protein dan kadar lemak ransum. Kadar lemak dalam ransum akan berpengaruh terhadap penimbunan lemak. Mahfudz et al (2011) menyatakan bahwa lemak abdominal apabila lemak karkas meningkat.

Hasil penilitian didapatkan persentase lemak abdominal berkisar antara 0,42

- 0,58 \%. Pada penelitian Bintang et al. (1997) melaporkan rata-rata persentase lemak abdominal itik lokal berkisar 0,55-0,89 \% . Faktor yang mempengaruhi pembentukan lemak abdominal umur, jenis kelamin, spesies, kandungan nutrisi, dan suhu lingkungan, Setiawan dan Sujana (2009) menyatakan pembentukan lemak tubuh pada unggas terjadi karena kelebihan energi yang dikonsumsi. Energi yang dimanfaatkan tubuh berasal dari karbohidrat dan cadangan lemak. Menurut Mahfudz et al. (2011) sumber karbohidrat dalam tubuh mampu memproduksi lemak yang disimpan di sekeliling jeroan dan dibawah kulit.

\section{Bobot Badan Akhir}

Bobot badan akhir itik magelang jantan yang diberi pemberian limbah kulit kecambah kacang hijau tidak berpengaruh. Hal ini disebabkan perlakuan pemberian limbah kecambah kacang hijau tidak memberikan dampak terhadap pertambahan bobot badan ternak . Hal tersebut dimungkinkan oleh tingkat konsumsi ransum. Soeharsono (1977) konsumsi ransum mempengaruhi pertumbuhan, dikarenakan konsumsi ransum menunjukkan konsumsi kandungan nutrisi. Pemberian limbah kecambah kulit kacang hijau hingga taraf 15 $\%$ memberikan nilai konsumsi ransum yang tidak berbeda nyata. Hal tersebut membuat kecernaan protein yang tidak berbeda nyata. Hal ini menyebabkan pada pembentukan jaringan. Mangisah et al (2009) pada itik yang mendapat pengaruh pemberian tepung tepung daun eceng gondk terfermentasi hingga taraf $21 \%$ memiliki nilai kecernaan protein di sekitar 68,19- 80,28\%.

Faktor yang mempengaruhi pada bobot badan akhir itik adalah kandungan nutrien ransum. Peamanfaatan limbah kecambah kacang hijau dalam ransum tidak memberikan perbedaan pada kadar protein ransum, sehingga tidak berpengaruh pada bobot badan akhir itik magelang. Nilai nutrisi pada ransum dengan Penggunaan limbah kecambah kacang hijau berbeda pada kandungan serat kasar masingmasing perlakuan. Itik masih mampu memanfaatkan kandungan serat kasar dalam ransum sampai 15\%. Mangisah., et al (2008) menyatakan serat kasar ransum sampai $15 \%$ tidak menurunkan konsumsi ransum.

\section{KESIMPULAN}

Berdasarkan hasil penelitian yang dilakukan dapat disimpulkan bahwa penggunaan tepung limbah kecambah sampai taraf $15 \%$ menurunkan energi metabolis tetapi tidak meningkatkan bobot badan akhir itik Magelang jantan, serta belum mampu menurunkan kadar lemak abdominal terhadap itik magelang jantan.

\section{REFERENSI}

Abun. 2007. Pengukuran Nilai Kecernaan Ransum yang mengandung Limbah Udang Windu Produk Fermentasi pada Ayam Petelur. Makalah Ilmiah. Universitas Padjadjaran. Jatinangor.

Badan Standardisasi Nasional Indonesia 2006. SNI. 01-3908-2006: Pakan Itik Meri (Duck Starter).

Bintang, I, A, K,. M. Silalahi, T. Antawidjaya dan Y.C. Rahardjo. 1997. Pengaruh berbagai tingkat kepadatan gizi ransum terhadap kinerja pertumbuhan itik jantan lokal dan silangannya. Balai Penelitian Ternak Bogor. Bogor.

Dewanti, R,, M. Irham dan Sudiyono. 2013. Pengaruh penggunaan eceng gondok (Eichornia crassipes) terfermentasi dalam ransum terhadap persentase karkas, nonkarkas dan lemak abdominal itik lokal jantan umur delapan minggu, Buletin Peternakan. 37(1):19-25 
Imawan, M. R. Sutrisna, R. Kurtini T. 2016. Pengaruh Ransum dengan Kadar Protein Kasar berbeda Terhadap Pertumbuhan Itik Betina Mojosari. Jurnal Ilmiah Peternakan Terpadu: 4(4): 300-306.

Mahfudz. L. D., T. A. Sarjana dan W. Sarengat. 2011. Efisiensi Penggunaan Protein Ransum yang Mengandung Limbah Destilasi Minuman Beralkohol (LDMB) Oleh Burung Puyuh (Coturnix coturnix japonica) Jantan. Seminar Nasional Teknologi Peternakan dan Veteriner 2010. Fakultas Peternakan, Universitas Diponegoro. Semarang. Hal. 887-894.

Mangisah. I., M.H. Nasoetion, W. Murningsih dan Arifah. 2008. Pengaruh serat kasar ransum terhadap pertumbuhan, produksi dan penyerapan volatile fatty acids pada itik tegal. Majalah Ilmiah Peternakan : 10 (3) : 83-88.

Mangisah. I., B. Sukamto dan M. H. Nasution. 2009. Implementasi daun eceng gondok fermentasi dalam ransum itik. Journal Indonesia Tropical Animal Agriculture. 34 (2) : 127-133.

Maryuni, S. S. dan C. H. Wibowo. 2005. Pengaruh Kandungan Lisin dan Energi Metabolis dalam Ransum yang mengandung Ubi Kayu Fermentasi terhadap Konsumsi Ransum dan Lemak Ayam Broiler. J. Indon. Trop. Anim. Agric. 30(1):26-33.

Poendjiadji A. 2005. Dasar-dasar biokimia. UI Press. Jakarta.

Rahayu, I., Sudaryani, T., dan Santosa, H. 2011. Panduan Lengkap Ayam. PT. Penebar Swadaya. Jakarta.

Saputra, P. H., O, Sjofjan dan I. H. Djunaidi. 2001. Pengaruh Pemberian Fitobiotik meniran(Phyllanthus niruri, L.) dalam pakan terhadap kecernaan protein kasar dan energi metabolis ayam pedaging. Universitas Brawijaya. Malang.
Setiawan. I dan E. Sujana. 2009. Bobot Akhir, Persentase Karkas dan Lemak abdominal Ayam Broiler yang Dipanen pada umur yang berbeda. Seminar Nasional Fakultas Peternakan Unpad "Pengembangan Sistem Produksi dan Pemanfaatan Sumber daya Lokal Untuk Kemandirian Pangan Asal Ternak". Bandung. ISBN:978-602-95808-0-8.

Soeharsono. 1977. Respon Ayam Broiler terhadap Berbagai Kondisi Lingkungan, Universitas Padjajaran. Bandung. (Disertasi Doktor),

Supriyadi. 2009. Panduan Lengkap Itik. Penebar Swadaya. Jakarta

Maryuni, S. S. dan C. H. Wibowo. 2005. Pengaruh Kandungan Lisin dan Energi Metabolis dalam Ransum yang mengandung Ubi Kayu Fermentasi terhadap Konsumsi Ransum dan Lemak Ayam Broiler. J. Indon. Trop. Anim. Agric. 30(1):26-33.

Tanwiriah, W., D. Garnida dan I.Y. Asmara. 2006. Pengaruh Tingkat Protein dalam Ransum terhadap Performan Entok Lokal pada Periode Pertumbuhan. Seminar Teknologi Peternakan dan Veteriner. Fakultas Peternakan Universitas Padjajaran. Bandung.

Yuniarti, M. Fajar, W. Vitus, D, Y, B, I. 2015. Kecernaan protein dan energy metabolis akibat pemberian zat aditif cair buah naga merah (Hylocereus polyrhizus) pada burung puyuh japonica betina umur 16-50 hari. Jurnal Ilmu-Ilmu Peternakan. 25(3): 45-52. 